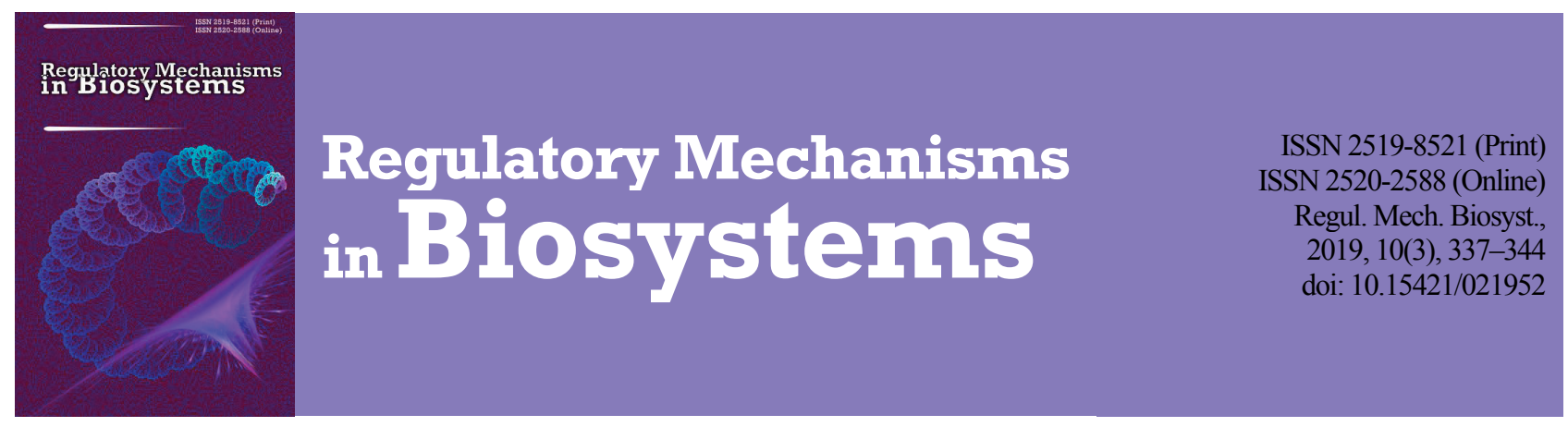

\title{
The influence of clonal micropropagation on productivity and differentiation of Mentha piperita plant tissues
}

\author{
T. E. Talankova-Sereda*, J. V. Kolomiets*, A. V. Holubenko**, N. V. Nuzhyna** \\ *National University of Life and Environmental Sciences of Ukraine, Kyiv, Ukraine \\ **Taras Shevchenko National University of Kyiv, Kyiv, Ukraine
}

Article info

Received 11.07.2019

Received in revised form 18.08 .2019

Accepted 19.08.2019

National University

of Life and Environmental

Sciences of Ukraine, Henera-

la Rodimtseva st., 19/4, Kyiv

03041, Ukraine.

Tel.: + 38-050-983-58-53

E-mail: $t a-$

tazp77@gmail.com

Taras Shevchenko

National University of Kyiv,

Simon Petliura st., 1 ,

Kyiv, 01032, Ukraine.

Tel.: +38-050-442-51-14

E-mail:

holubenko@yahoo.com
Talankova-Sereda, T. E., Kolomiets, J. V., Holubenko, A. V., \& Nuzhyna, N. V. (2019). The influence of clonal micropropagation on productivity and differentiation of Mentha piperita plant tissues. Regulatory Mechanisms in Biosystems, 10(3), 337-344. doi:10.15421/021952

Peppermint grass, as a raw medicinal plant material, has great importance for the pharmaceutical industry. The influence of clonal micropropagation and chemotherapy has been established in vitro on six breeds of Ukrainian selection peppermint plants, in particular on the sprouts' conductive system structure and tissue development, general biomass accumulation, and in vivo productivity of breeds. The influence of clonal micropropagation and chemotherapy on important productivity indices of the plants has been established in vitro in six breeds of Ukrainian selection peppermint plants as pharmacopeial plants. The linear meter method, the microscopic method, the standard histochemical methods, and the statistical analysis method were used in the studies. A clear tendency to increase in the leaf cover, air-dry leafage and rhizome was observed in breeds of Ukrainian selection peppermint to which propagation and in vitro improvement technology was applied. The air-dry leafage yield significantly increased after in vitro culture from $7.6 \%$ in the Lidiia breed to $51.4 \%$ in the Chornolysta breed recognized as a state mint standard in Ukraine. The leaf cover increased from $8 \%$ to $21 \%$ in peppermint plants improved in in vitro culture. This method promoted essential oil quantity increase from 9.8 to $28.6 \mathrm{~kg}$ per hectare. The rhizome yield increased by $6.3-40.4 \%$ in all peppermint plants breeds after improvement in in vitro culture on average within one vegetation year. The Lebedyna Pisnia and Mama breeds were characterised by the most intensive development of all investigated anatomic and morphological indices after in vitro culture: rhizomes yield increased by $40.4 \%$ and $40.1 \%$, air-dry leafage by $37.1 \%$ and $26.6 \%$, leaf cover by $21.0 \%$ and $13.0 \%$, and essential oil quantity per hectare increased by $38.1 \%$ and $28.5 \%$ accordingly. Anatomical and histochemical studies of sprouts of Ukrainian selection peppermint plants breeds confirmed increase in xylogenesis intensity in the majority of the studied breeds (except Lidiia and Ukrains'ka Pertseva) after in vitro culture improvement. The xylogenesis process was most expressed in the Mama and Chornolysta breeds. Air-dry leafage, rhizome yield, and leaf cover increased in all peppermint plants breeds after in vitro improvement, which could be critical for the pharmaceutical industry.

Keywords: Mentha piperita; in vitro; yield; xylogenesis.

\section{Introduction}

Peppermint (Mentha piperita L.) is a widespread valuable essential oil medicinal cultivar, which is a source of pharmaceutical leaf and essential oil derivation. It is also a source of various components which are widely used in the chemical and pharmaceutical, perfume and cosmetic, confectionery, food, alcoholic beverage, tobacco, paint and coatings industries and medicine (Tkachenko, 2011).

Essential oil morphological signs and component structure polymorphism are characteristic for peppermint breeds (or the Mentha species plants). Vegetative propagation by rhizome sections and sprouts is mainly used for propagation of this culture, but unfortunately this technique also promotes accumulation phytopathogens of various aetiology. There are several mechanisms that can be utilized for the protection of the plants, for example, multifunctional enzyme peroxidase participates in strengthening cell walls, protection from viral, bacterial and fungus pathogens (Rogozhin, 2004; Burhanova, 2006; Yusupova, 2006; Mehdi Talebi et al., 2018). During hydrogen peroxide destruction it forms activated free radicals, which have antimicrobial characteristics. These radicals cause low-molecular phenol compounds' polymerisation, thus assisting in forming polymers, such as M-lignin and suberin (Hawkins \& Boudet, 2003; Kawano, 2003). Apart from peroxidise, polyphenol oxidases, laccases (phenoloxidases), phenylalanine ammonia lyase (PAL), pyro-catechin-o-methyltransferase, n-coumaroyl-CoA ligase, hydroxycinnamate-CoA ligase, cynnamoyl-CoA reductase, and cinnamyl alcohol dehydrogenase are key enzymes in M-lignin components synthesis. Basic quantities of M-lignin are synthesised during formation of the conductive elements of the xylem (Aleksandrova, 1994). The lignification process leads to mechanical barrier build-up and promotes accumulation of phenol compounds toxic for pathogens. This process prevents spread of infection, limits water and nutrients exchange, and protects plants cells walls from action of hydrolytic enzymes of phytopathogens (Veljovic-Jovanovic, 2006). Phenols, in turn, are oxidation-catalysed reaction co-factors of many peroxidase substrates, and participate in metabolic processes and defence reactions.

Currently, peppermint in Ukraine suffers from numerous viral diseases (Mishhenko et al., 2014) and the only realistic way to solve this problem is clonal micropropagation and improvement in in vitro culture using virucide Ribavirin (1- $\beta$-D-ribofuranosyl-1,2,4-triazole-3-carboxamide, "Sigma-Aldrich", USA) in $10 \mathrm{mg} / \mathrm{L}$ concentration (TalankovaSereda et al., 2016). Virus carrying testing by electron microscopy methods and biological testing perfomed by Mishchenko et al. (2016) with Ribavirin use has shown negative results. Adoption of in vitro technology for improving the health and micropropagation of plants allows one to receive plants identical to the parent breed, which are free from viral, bacterial and fungus pathogens. In field conditions intensive and 
homogeneous development with raised resistance to adverse conditions is observed. Plants have a more developed root system which is capable of fast growth and regeneration. Plantation exploitation durability is observed without yield decrease and signs of breed degeneration. Also the in vitro culture gives the opportunity to obtain in a short period a considerable quantity of homological progeny of industrially valuable breeds or breed samples and to reserve valuable genotypes. The peculiarity of peppermint as an essential oil plant is the presence of secretory structures glands (trichomes). They are located on peppermint leaves and the caulis (Lange et al., 2000; Tissier, 2012) and secrete lipophile substances, namely essential oils, whose basic components are monoterpenes.

Menthol is the most important peppermint essential oil component. Its content depends on breed features, conductive system development, hormonal status, agrotechnical conditions of cultivation, plant age, etc. (Tanasienko, 1985; Kirichenko, 2008; Knyazyuk \& Kozak, 2017). In our earlier research, we established the content of menthol and other major components of vegetatively propagated peppermint plants and plants after improvement in culture (Talankova-Sereda et al., 2018).

The plant, as a functionally complex system, coordinates development of different tissues. It is established that phloem parenchyma participates in intercellular translocation of metabolites and biological synthesis of monoterpene precursors, and it is the basic place of isoprenoid biosynthesis (Burlat et al., 2004). Besides, phloem parenchyma cells contain various inclusions: starch, crystals (Kuin', 2011). These cells also play a key function in biosynthesis of different specific compounds, for example ABA synthesis (Endo et al., 2008), protosystemin synthesis (Narváez-Vásquez \& Ryan, 2004) and jasmonic acid synthesis, which influence phloem development and phloem parenchyma participation in lipid metabolism, and this is very important for essential oil cultures.

Morphological, anatomical and histochemical peppermint characteristics are an integral part of identification of raw medicinal plant material in order to establish its quality indices for the pharmaceutical industry. The microscopic diagnostics signs of raw medicinal plant materials for "peppermint grass" are specified in State Pharmacopoeia Requirements. These signs are form and size of epidermis cells, stomata type, presence and structure of trichomes, presence of essential oil glands and crystal inclusions and also disposition peculiarities of mechanical and conductive tissues (The State Pharmacopoeia of Ukraine, 2014).

Therefore the aim of the work is to establish the influence of clonal micropropagation and improvement of the health of peppermint plants through in vitro culture on structure and development of conductive system tissues of sprouts, general biomass accumulation and productivity of breeds in vivo.

\section{Materials and methods}

The research objects are the peppermint (Mentha piperita L.) plants of the Lebedyna Pisnia, Lubenchanka, Lidiia, Ukrains'ka Pertseva, Mama, Chornolysta breeds, which have been propagated by the vegetative method, and these same breeds after improvement in in vitro culture with the use of chemotherapy. The Lebedyna Pisnia breed is cultivated for pharmaceutical leaf derivation and for essential oil processing. The Lubenchanka breed is used for chemical and pharmaceutical industry technical purposes - essential oil and menthol derivation. The Lidiia, Mama, Chornolysta breeds are used for pharmaceutical leaf derivation and for producing herbal medicinal mixtures and herbal teas. The Chornolysta breed is the oldest cultivated breed in Ukraine and has been grown under industrial conditions for a long time (Grodzins'kij, 1992; Shelud'ko, 2004). The peppermint caulis is upright, with the height about $1 \mathrm{~m}$, tetraquetrous, densely leaved, heavily branched. A characteristic of the Mama breed is the considerable quantity of inflorescences quantity on the plant ( $15 \%$ of the plant's above-ground weight).

The research was conducted in July-August 2017 in the "Problem research laboratory of phytovirology and biotechnology of the National University of Life and Environmental Sciences of Ukraine" within the framework of the scientific theme "Biotechnological foundations of Lamiaceae family essential oil plants propagation for obtaining highquality planting material" (state registration number 0116U001994).
In vitro isolated tissues and organs culture and chemotherapy methods have been used for peppermint improvement. For this we used Murashige \& Skoog (1962) nutrient medium modification with $0.75 \mathrm{mg} / \mathrm{L}$ BAP, $0.1 \mathrm{mg} / \mathrm{L}$ adenine, $0.05 \mathrm{mg} / \mathrm{L}$ indolebutyric acid (IAA) and $0.5 \mathrm{mg} / \mathrm{L}$ gibberellic acid (GA) growth regulators and virucide Ribavirin (1- $\beta$-Dribofuranosyl-1,2,4-triazole-3-carboxamide, "Sigma-Aldrich", USA) in $10 \mathrm{mg} / \mathrm{L}$ concentration addition during the second passage from the beginning of aseptic culture introduction (Talankova-Sereda et al., 2016). The plants were cloned on MS nutrient medium with the similar composition without virucide addition after the chemotherapy, and were then rooted. These plants were adapted to in vivo conditions during the month.

Six experiments were conducted by the transplantation method in quadruple repetition annually from 2015 till 2018 in field conditions in Lubensky district of Poltava oblast in the territory of the Research Station of Medicinal Plants of the Institute of Agroecology and Nature Management of NAAS of Ukraine. Peppermint Lebedyna Pisnia, Lubenchanka, Lidiia, Ukrains'ka Pertseva, Mama, Chornolysta breeds were tested in these experiments. The above mentioned breeds are registered in the Register of Breeds Suitable for Distribution in Ukraine (Derzhavnij reestr sortiv roslin pridatnih do poshirennja v Ukrajini, 2019). Two variants were tested: the first control variant was made with planting material for each breed, which was vegetatively propagated and not improved; in the second variant (experimental) planting material improved by clonal micropropagation and chemotherapy was used.

The experimental plots were five-row. The length of one row was $10 \mathrm{~m}$. The total plot area was $23 \mathrm{~m}^{2}$. The distance between plants was $20 \mathrm{~cm}$ (250 plants on a plot). Border strips were made with that same breed which has been tested in experiment. Lateral border strips were $0.9 \mathrm{~m}$ (by two rows), the border strip length before experiment and after experiment was $2 \mathrm{~m}$. Observations and recordings were made after establishment of the trial. Phenological observations were made visually for the total quantity of plants on a plot. The edaphoclimatic conditions of the region in which the research was conducted are considered to be productive for peppermint propagation.

Raw material yield recording was performed in the mass blossoming phase by the linear meter method (Moloc'kij et al., 2006, Eshhenko et al., 2014). The rhizomes yield was assessed in autumn after the vegetative period end. Rhizomes' excavation was done on that part of the plot where collection of the above-ground part of the plantt was not done. Raw material collecting is not allowed in seed farming practice, when the planting material is grown. Cutting the above-ground part has a negative effect on the quality of the rhizomes due to outflow of nutrients through regrowth of the aftergrass. The dug up rhizomes were separated from the parent plant and weighed. Then recalculation on unit area was carried out and the rhizomes yield determined.

Histochemical and anatomical examination of the sprouts was perfomed on transversal sections of native preparations of caules, which were made in a midsection between 2 and 3 nodes. Native preparations were studied by means of microscope Nikon Eclipse E-200 (Japan).

Starch, peroxidase and M-lignin components localisation in the sprouts was defined by the standard histochemical methods (Furst, 1979; Pausheva, 1988). Staining for detection of starch was performed using Lugol's solution, for peroxidase detection - using benzidine (Kleyn \& Kleyn, 1974), for M-lignin detection - using potassium permanganate, $1 \mathrm{M}$ chloric acid, ammonium hydroxide.

Data photographic documentation was performed by means of software Camera Control Pro 2 (Nikon Corporation, Japan). Analysis of metric indices of the peppermint sprouts' structure was performed with use of specialised software Image-Pro Premier 9.0 (Media Cybernetics, USA).

The results were statistically analyzed in the Statistica 10.0 (StatSoft Inc., USA) program pack. The tables and figures show the arithmetic mean values and their standard errors $(x \pm S E)$. The reliability of the differences between the samples was evaluated using the single-factor dispersion analysis ANOVA. The Bonferroni pairwise test was carried out after ANOVA for the determination of significant differences $(\mathrm{P}<$ 0.05 ) between the means of the values obtained for each groups. Correlations between the obtained indices were determined using the Spearman non-parametric criterion. 


\section{Results}

The peppermint plants' sprout stem was tetraquetrous in all tested breeds. The conductive system was of collateral type, phloem located towards the caulis periphery, and xylem - to the centre. The peculiarity of peppermint as an essential oil plant is the presence of secretory structures located on the plant's leaves, sprouts and rhizomes. The epidermis has induviate and glandular hairs. Induviate hairs are lengthened multicellular, have from 3 to 8 cells. Glandular hairs consist of three cells basal, cell - stalk, small head. According to literature data, two glandular trichomes types are characteristic for Mentha species representatives small capitate glandular trichomes, which consist of single-celled stalk and capitate cell; and also glandular trichomes, which have a rounded small head. This small head is an eight-celled apical cluster of glandular cells, where essential oil is accumulated. Glandular trichomes with singlecelled small head and multicellular non-glandular trichomes were revealed in all tested breeds (Fig. 1). Epidermal cells are of the lengthened shape with an easily noticeable cuticle. Collenchyma forms a dense ring in the peppermint primary cortex, which on the ribs forms 10-12 rows of tissue cords. Collenchyma cell walls have thickenings at the corners. These thickenings with neighbouring cells walls form triangles and pentagons. Well organized opened collateral fibrovascular bundles are more developed on the sprout edges. A single-layered epidermis is seen on the peppermint sprout transversal section. It consists of rectangular cells with the thickened external cell wall (Fig. 2).

Research on the height of the epidermis of vegetatively propagated and after in vitro culture peppermint sprouts shows that epidermis thickening is characteristic for the majority of improved breeds, except Lubenchanka and Chornolysta breeds (Fig. 3).

Statistically significant increase in epidermis height was observed in two breeds: in the Lidiia breed by $8.5 \%$, in the Mama breed by $16.8 \%$. The epidermis height statistically significantly decreased by $8.9 \%$ in the Lubenchanka breed and by $12.1 \%$ in the Chornolysta breed.

The histochemical reaction of the tissues was observed at staining of fresh sections with benzidine. This reaction testifies to peroxidase localisation - dark blue colour (Fig. 4). The enzyme shows the greatest activity in phloem tissues, collenchyma and cortex cells. More intensive staining was observed in vegetatively propagated plants (Fig. $4 a$ ), the reaction to peroxidase was weaker in the improved peppermint plants in in vitro culture (Fig. $4 b$ ). The secondary xylem of the caulis is of the diffuse-porous type. The histochemical reaction of the vessels' cell walls to M-lignin was observed in the peppermint sprouts' second internode. In all peppermint breeds more intensive staining was observed in the unimproved vegetatively propagated plants (Fig. 5).

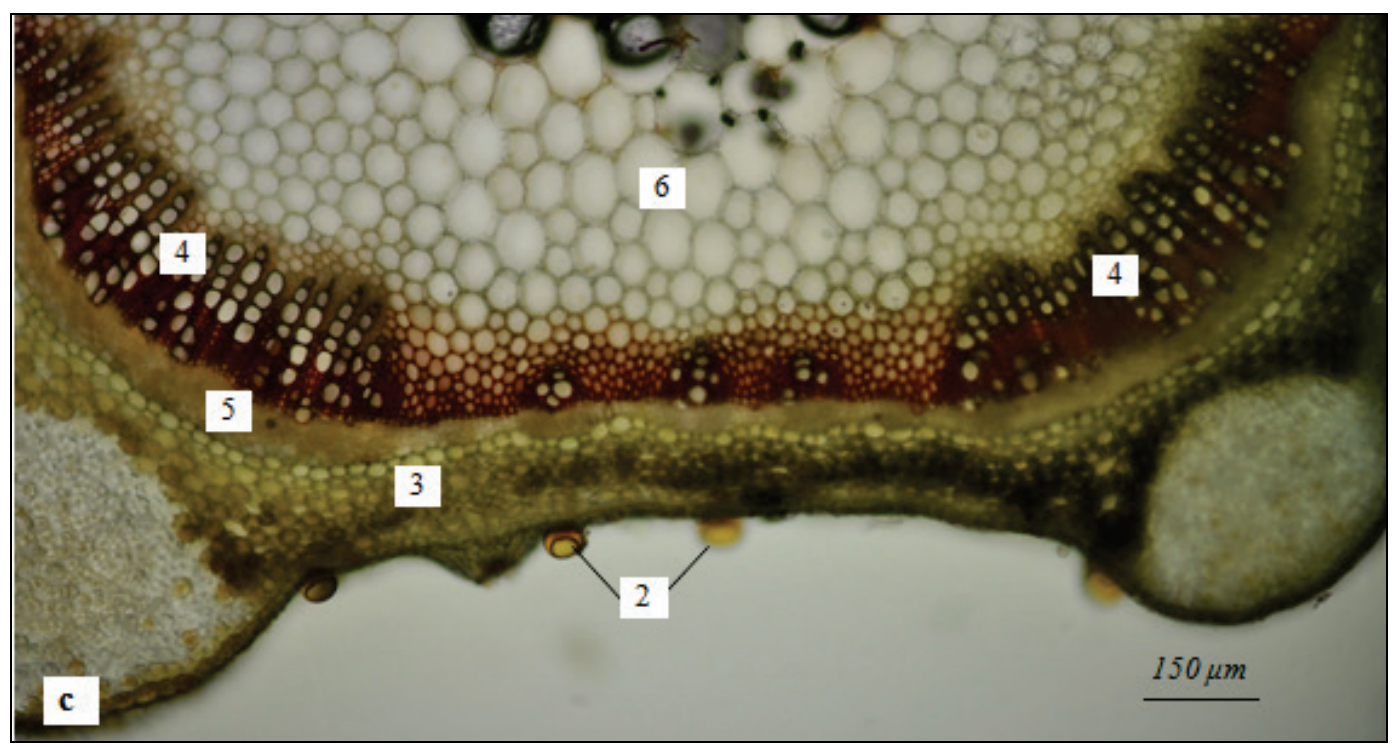

Fig. 1. Ukrains'ka Pertseva breed peppermint caulis anatomical section: $a, b$-secretory structures on the peppermint caulis surface; $c$-peppermint caulis transversal section; 1 -non-glandular trichomes; 2 -glandular trichomes; 3 - cortex; 4-xylem, 5-phloem; 6 - pith parenchyma

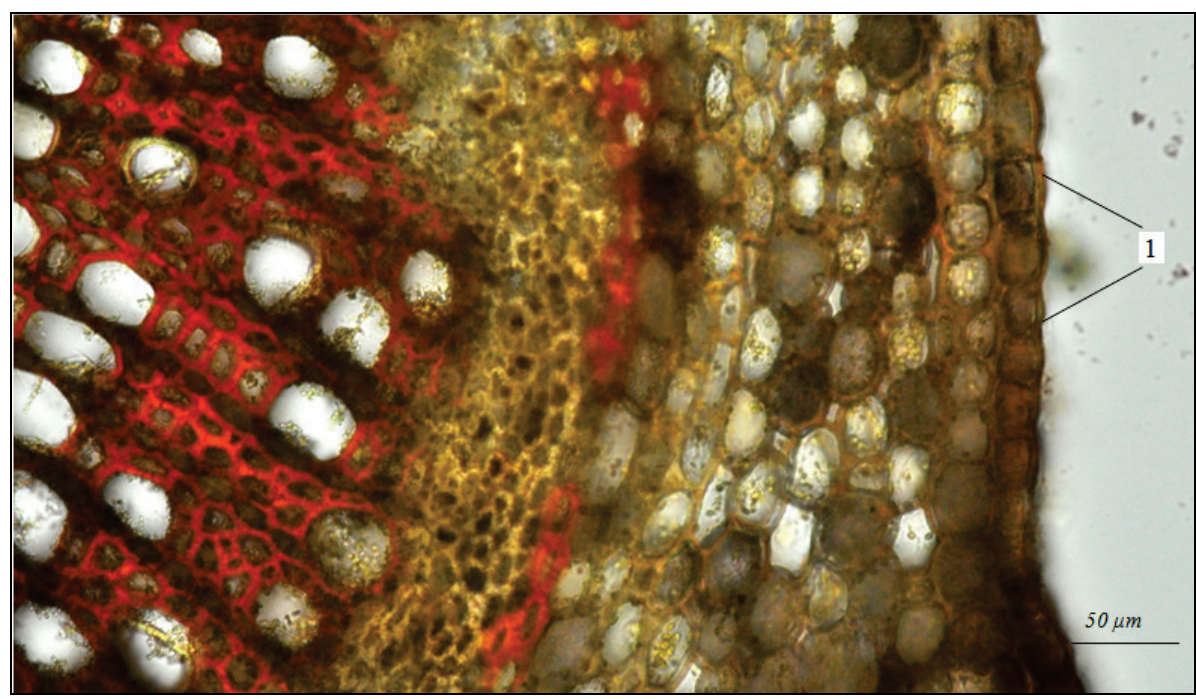

Fig. 2. Lebedyna Pisnia breed peppermint sprout fragment: 1 - epidermis 


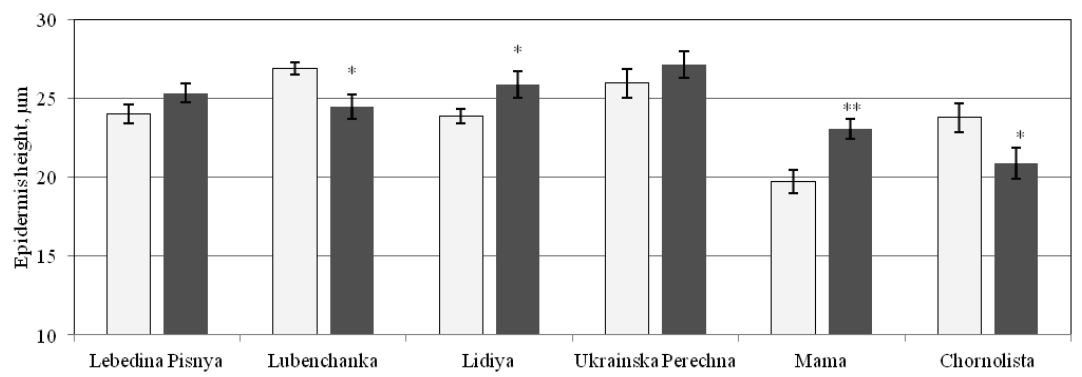

Fig. 3. Anatomical indices of sprouts epidermis of Ukrainian selection peppermint plants ( $\mu \mathrm{m}, \mathrm{x} \pm \mathrm{SE}, \mathrm{n}=10)$ : white colour - control (vegetative reproduced plants); grey colour - plants treated in culture in vitro; ${ }^{*}$ - differences are statistically significant at $\mathrm{P}<0.05$ compared with the control;** $-\mathrm{P}<0.01$ (with Bonferroni correction)

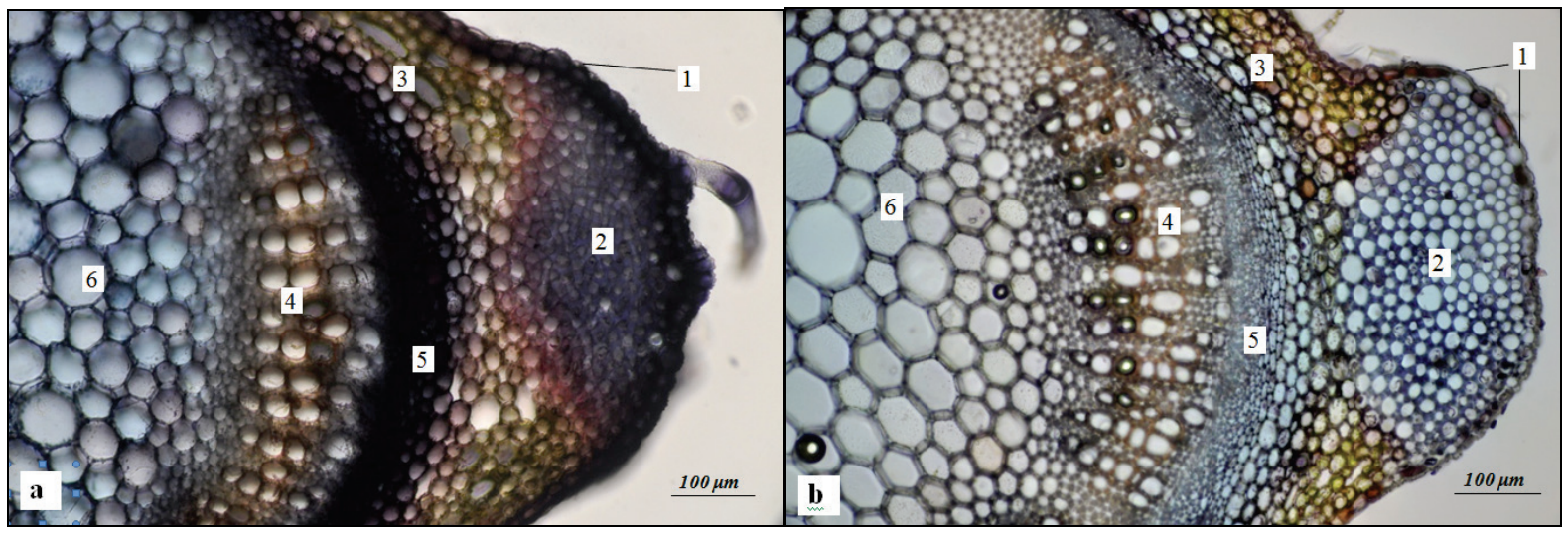

Fig. 4. Localisation of peroxidases in peppermint caulis tissues (benzidine reaction with dark blue colour products formation): $a$ - vegetative reproduced plants; $b$ - plants treated in culture in vitro; 1 - epidermis; 2 - collenchyma; 3 - cortex; 4 -xylem; 5 - phloem; 6 - pith parenchyma

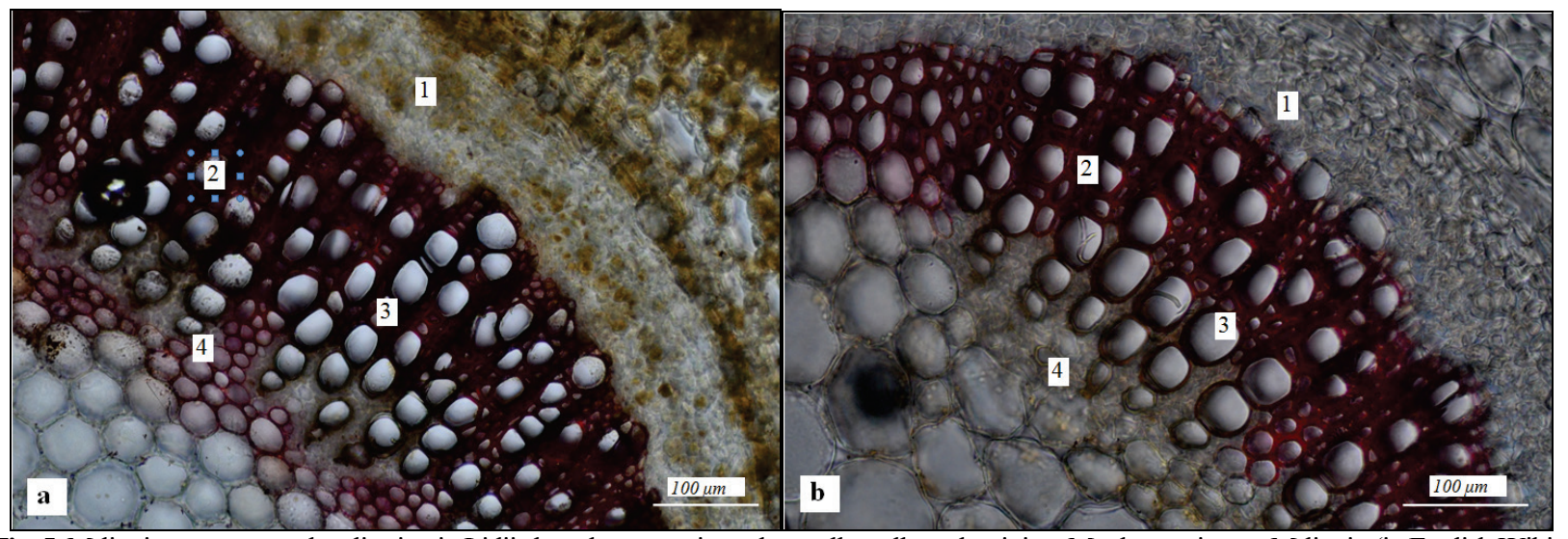

Fig. 5. M-lignin components localisation in Lidiia breed peppermint xylem cells walls: red staining, Meule reaction on M-lignin (in English WikiWiesner test): $a$-vegetative reproduced plants; $b$-plants treated in culture in vitro; 1 -phloem; 2 -xylem; 3 -vessels of metaxylem; 4 -protoxylem

Fibrovascular bundles on the edges have a phloem to xylem ratio $1: 3$ in the majority of vegetatively propagated peppermint plants. The majority of peppermint breeds preserved a phloem to xylem ratio $1: 3$ after propagation and in vitro improvement, and in two breeds, Mama and Lubenchanka, it changed to $1: 4$. Change in cortex, xylem and phloem thickness was observed in peppermint plants after in vitro improvement in comparison with vegetatively propagated plants (Table 1).

The cortex thickness decreased in the Lebedyna Pisnia, Mama and Chornolysta breeds, and a tendency to increase was observed in the Lidiia and Ukrains'ka Pertseva breeds. This index did not change in the Lubenchanka breed. The xylem thickness increased in the majority of the peppermint breeds after cloning except the Lidiia and Ukrains'ka Pertseva breeds. The phloem thickness increased only in two breeds - Ukrains'ka Pertseva and Mama. This index did not change in the Chornolysta breed and decreased in the Lebedyna Pisnia, Lubenchanka and Lidiia breeds. Analysis of the ratio of xylem/cortex and xylem/phloem in vegetatively propagated and cloned plants showed increase in the xylem to phloem ratio in the Lebedyna Pisnia, Lubenchanka, Mama and Chornolysta breeds.
Table 1

Anatomical characteristics of transversal sections of sprouts of peppermint breeds of Ukrainian selection $(\mu \mathrm{m}, \mathrm{x} \pm \mathrm{SE}, \mathrm{n}=10)$

\begin{tabular}{lcccc}
\hline \multirow{2}{*}{$\begin{array}{c}\text { Pepper mint } \\
\text { breeds }\end{array}$} & \multirow{2}{*}{ Variants } & \multicolumn{3}{c}{ Thickness } \\
\cline { 3 - 5 } Lebedyna Pisnia & control & $67.7 \pm 2.6$ & $175.5 \pm 7.9$ & cortex \\
& in vitro & $60.7 \pm 1.7^{*}$ & $202.4 \pm 7.7^{*}$ & $71.1 \pm 3.0$ \\
Lubenchanka & control & $60.5 \pm 2.6$ & $187.5 \pm 7.0$ & $61.1 \pm 2.2$ \\
& in vitro & $60.7 \pm 1.4$ & $199.8 \pm 5.9$ & $53.3 \pm 2.2^{*}$ \\
Lidiia & control & $65.8 \pm 1.9$ & $226.4 \pm 8.0$ & $67.0 \pm 0.8$ \\
& in vitro & $69.1 \pm 2.4$ & $188.3 \pm 4.5^{* *}$ & $62.5 \pm 2.4$ \\
Ukrains'ka Pertseva & control & $58.0 \pm 2.2$ & $202.2 \pm 5.7$ & $60.3 \pm 2.0$ \\
& in vitro & $62.4 \pm 1.6$ & $181.5 \pm 4.9^{*}$ & $79.0 \pm 2.6^{* *}$ \\
Mama & control & $62.4 \pm 2.9$ & $185.8 \pm 7.1$ & $54.0 \pm 1.2$ \\
& in vitro & $53.7 \pm 1.3^{*}$ & $250.4 \pm 8.1^{* *}$ & $62.5 \pm 2.4^{* *}$ \\
Chornolysta & control & $57.1 \pm 1.4$ & $182.5 \pm 6.9$ & $74.1 \pm 4.8$ \\
& in vitro & $53.3 \pm 2.7$ & $209.6 \pm 7.8^{*}$ & $73.3 \pm 3.5$ \\
\hline
\end{tabular}

Notes: control - vegetative reproduced plants; in vitro - plants treated in culture in vitro; * - differences are statistically significant at $\mathrm{P}<0.05$ compared with the control; $* *-\mathrm{P}<0.01$ (with Bonferroni correction). 
Xylem to phloem ratio decrease was observed in the Lidiia and Ukrains'ka Pertseva breeds. Xylem to cortex ratio increased in the Lebedyna Pisnia, Lubenchanka, Mama and Chornolysta breeds. In other breeds (Lidiia and Ukrains'ka Pertseva) it decreased (Fig. 6).

It is established that metaxylem vessels diameter statistically significantly changed in vegetatively propagated plants and plants improved in in vitro culture in the Lebedyna Pisnia, Mama, Lubenchanka and Chornolysta breeds (Fig. 7). The metaxylem vessels diameter considerably decreased in the Lebedyna Pisnia and Mama breeds after in vitro clonal micropropagation, and increased in the Lubenchanka and Chornolysta breeds.

The economic value of peppermint breed plants, as essential oil culture, is due to air-dry leafage yield $\left(\mathrm{kg} / \mathrm{m}^{2}\right)$, which significantly increased in all breeds after in vitro culture from $7.6 \%$ in the Lidiia breed to $51.4 \%$ in the Chornolysta breed. Besides, rhizome yield increase was observed by $6.3-40.4 \%$ after improvement. Significant increase of these indices led to increase in essential oil quantity per hectare from 9.8 to $28.6 \mathrm{~kg}$, that is $11.6-54.4 \%$ in percentage ratio (Table 2).

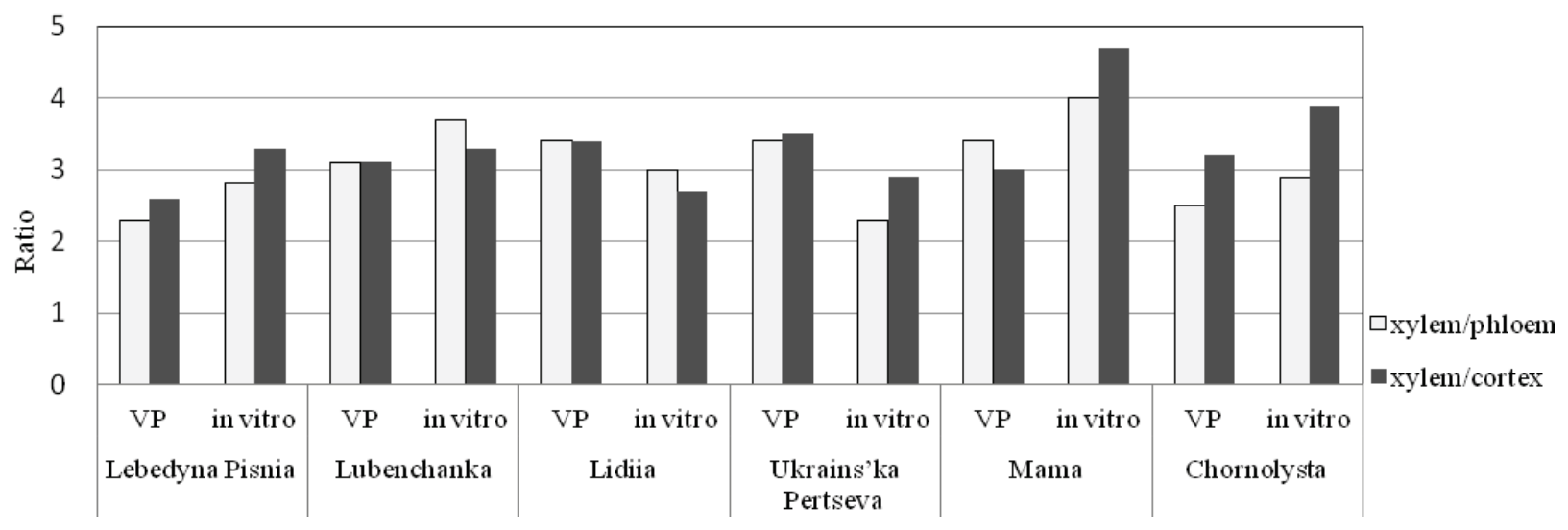

Fig. 6. Xylem/cortex and xylem/phloem ratio in the caules of M. piperita plant breeds of Ukrainian selection: $\mathrm{VP}$ - (control) vegetatively propagated plants; in vitro - plants improved in in vitro culture

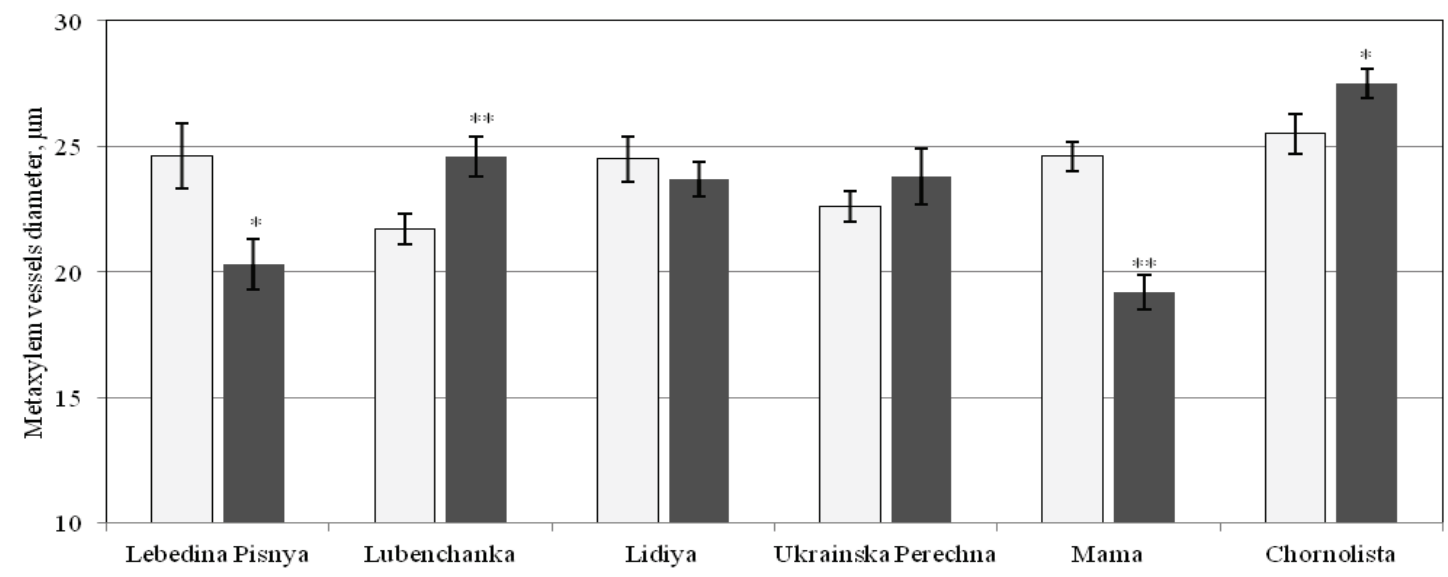

Fig. 7. Metaxylem vessels diameter $(\mu \mathrm{m}, \mathrm{x} \pm \mathrm{SE}, \mathrm{n}=10)$ : white colour - control (vegetatively reproduced plants); grey colour - plants treated in culture in vitro; ${ }^{*}$ - differences are statistically significant at $\mathrm{P}<0.05$ compared with the control; $* *-\mathrm{P}<0.01$ (with Bonferroni correction)

Table 2

Productivity indices of Ukrainian selection peppermint plants (2015-2017, $\mathrm{x} \pm \mathrm{SE}, \mathrm{n}=10)$

\begin{tabular}{|c|c|c|c|c|c|}
\hline Peppermint breeds & Variants & $\begin{array}{l}\text { Air-dry leafage yield, } \\
\mathrm{kg} / \mathrm{m}^{2}\end{array}$ & $\begin{array}{l}\text { Rhizome yield, } \\
\mathrm{kg} / \mathrm{m}^{2}\end{array}$ & $\begin{array}{l}\text { Peppermint essential } \\
\text { oil quantity per } 1 \mathrm{ha}, \mathrm{kg}\end{array}$ & $\begin{array}{l}\text { Leaf cover, } \\
\%\end{array}$ \\
\hline \multirow{3}{*}{ Lebedyna Pisnya } & control & $0.186 \pm 0.0057$ & $1.53 \pm 0.024$ & 70.9 & 31 \\
\hline & in vitro & $0.255 \pm 0.0068 * *$ & $2.15 \pm 0.035^{* *}$ & 97.9 & 52 \\
\hline & ompared to the VP, $\%$ & 37.1 & 40.4 & 38.1 & 21 \\
\hline \multirow{3}{*}{ Lubenchanka } & control & $0.173 \pm 0.0033$ & $1.71 \pm 0.019$ & 69.0 & 32 \\
\hline & in vitro & $0.201 \pm 0.0052 * *$ & $2.08 \pm 0.022 * *$ & 80.8 & 47 \\
\hline & ompared to the VP, $\%$ & 16.2 & 21.4 & 17.1 & 15 \\
\hline \multirow{3}{*}{ Lidiia } & control & $0.262 \pm 0.0039$ & $1.34 \pm 0.020$ & 84.4 & 40 \\
\hline & in vitro & $0.282 \pm 0.0041^{*}$ & $1.42 \pm 0.022 * *$ & 94.2 & 49 \\
\hline & compared to the VP, $\%$ & 7.6 & 6.3 & 11.6 & 9 \\
\hline \multirow{3}{*}{ Ukrains'ka Pertseva } & control & $0.152 \pm 0.0036$ & $1.01 \pm 0.021$ & 55.3 & 38 \\
\hline & in vitro & $0.205 \pm 0.0045^{* *}$ & $1.28 \pm 0.023^{* *}$ & 75.6 & 46 \\
\hline & compared to the VP, $\%$ & 34.9 & 25.9 & 36.7 & 8 \\
\hline \multirow{3}{*}{ Mama } & control & $0.188 \pm 0.0042$ & $1.75 \pm 0.019$ & 73.7 & 39 \\
\hline & in vitro & $0.238 \pm 0.0047 * *$ & $2.45 \pm 0.016^{* *}$ & 94.7 & 52 \\
\hline & compared to the VP, $\%$ & 26.6 & 40.1 & 28.5 & 13 \\
\hline \multirow{3}{*}{ Chornolysta } & control & $0.140 \pm 0.0034$ & $0.96 \pm 0.016$ & 52.6 & 33 \\
\hline & in vitro & $0.212 \pm 0.0043 * *$ & $1.23 \pm 0.018^{* *}$ & 81.2 & 49 \\
\hline & compared to the VP, $\%$ & 51.4 & 28.5 & 54.4 & 16 \\
\hline
\end{tabular}

Notes: control - vegetatively propagated plants; in vitro - plants improved in in vitro culture; * - differences are statistically significant at $\mathrm{P}<0.05$ compared with the control, **- $\mathrm{P}<0.01$ (with Bonferroni correction). 
Important parameters of productivity of peppermint as a medicinal plant, which is a source of obtaining medicinal leaves and essential oil, are air dry leaf yield, leaf cover and amount of essential oil. Data analysis has shown that essential oil quantity increased from 9.8 to $28.6 \mathrm{~kg}$ per 1 ha in peppermint plants improved in in vitro culture. Leaf cover, which is the ratio of the leaves' weight to general peppermint aboveground weight increased after clonal propagation from $8 \%$ to $21 \%$. The highest increase in this index was for the Lebedyna Pisnia breed. Rhizome yield was lower by $6.3-40.4 \%$ in all peppermint plants breeds control variants. The most meaningful rhizome yield increase is noted in the high menthol Mama and Lebedyna Pisnia breeds, $40.1 \%$ and $40.4 \%$ accordingly, in the Lidiia breed this increase was minimal $-6.3 \%$. Rhizome yield increased from 8.4 to $70.2 \mathrm{~kg}$ in terms of the equivalent amount per hectare. Multiple correlation analysis by 12 indices revealed close interrelations between such indices as xylem thickness to cortex ratio and xylem thickness to phloem ratio (Table 3 ).

The correlation coefficients given in the above table imply the presence of authentically significant interrelations between indices, in particular $(\mathrm{P}<0.001)$ correlation coefficients between menthol and xylem/ cortex ratio, and also between menthol and rhizome yield are highly significant.

At the same time, correlation analysis performed on peppermint plants after clonal micropropagation in in vitro culture, for the same indicators as in vegetatively propagated plants, revealed more and closer interrelations between the indices (Table 4). Moreover, the quantity of highly significant $(\mathrm{P}<0.001)$ correlation coefficients, including between cortex and epidermis height, xylem and foliage, menthol and rhizome yield, considerably increased.

Table 3

Correlation analysis of indices of vegetatively propagated peppermint plants

\begin{tabular}{|c|c|c|c|c|c|c|c|c|c|c|c|}
\hline Indicators & Cortex & Xylem & Phloem & $\begin{array}{c}\text { Xylem/ } \\
\text { cortex }\end{array}$ & $\begin{array}{l}\text { Xylem/ } \\
\text { phloem }\end{array}$ & $\begin{array}{c}\text { Metaxylem } \\
\text { vessels diameter }\end{array}$ & $\begin{array}{l}\text { Epidermis } \\
\text { height }\end{array}$ & $\begin{array}{l}\text { Leaf } \\
\text { yield }\end{array}$ & $\begin{array}{c}\text { Rhizome } \\
\text { yield }\end{array}$ & Foliage & Menthol \\
\hline Xylem & -0.086 & - & - & - & - & - & - & - & - & - & - \\
\hline Phloem & 0.257 & -0.486 & - & - & - & - & - & - & - & - & - \\
\hline Xylem/cortex & $-0.829 * *$ & 0.371 & -0.029 & - & - & - & - & - & - & - & - \\
\hline Xylem/phloem & -0.464 & $0.812^{* *}$ & -0.203 & $0.812 * *$ & - & - & - & - & - & - & - \\
\hline Metaxylem vessels diameter & $-0.086^{* *}$ & $-0.600^{*}$ & 0.257 & 0.086 & -0.290 & - & - & - & - & - & - \\
\hline Epidermis height & -0.029 & 0.257 & 0.086 & -0.029 & 0.145 & $-0.886^{* *}$ & - & - & - & - & - \\
\hline Leaf yield & $0.829 * *$ & 0.314 & -0.143 & $-0.600^{*}$ & -0.145 & -0.086 & -0.257 & - & - & - & - \\
\hline Rhizome yield & 0.543 & -0.086 & -0.429 & $-0.829 * *$ & $-0.638^{*}$ & -0.200 & -0.029 & $0.600 *$ & - & - & - \\
\hline Foliage & -0.029 & $0.714^{* *}$ & -0.543 & 0.314 & $0.609^{*}$ & 0.086 & -0.486 & 0.486 & -0.029 & - & - \\
\hline Menthol & $0.714 * *$ & -0.257 & -0.257 & $-0.943^{* * *}$ & $-0.754 * *$ & -0.029 & -0.143 & $0.657^{*}$ & $0.943 * * *$ & -0.086 & - \\
\hline Menthone & -0.464 & -0.348 & 0.348 & 0.551 & 0.221 & 0.551 & -0.261 & $-0.638^{*}$ & -0.812 & -0.116 & $-0.638^{*}$ \\
\hline
\end{tabular}

Notes: $*-\mathrm{P}<0.05 ; * *-\mathrm{P}<0.01 ; * * *-\mathrm{P}<0.001$.

Table 4

Correlation analysis of indices of improved in vitro peppermint plants

\begin{tabular}{|c|c|c|c|c|c|c|c|c|c|c|c|}
\hline Indicators & Cortex & Xylem & Phloem & $\begin{array}{c}\text { Xylem/ } \\
\text { cortex }\end{array}$ & $\begin{array}{l}\text { Xylem/ } \\
\text { phloem }\end{array}$ & $\begin{array}{c}\text { Metaxylem } \\
\text { vessels diameter }\end{array}$ & $\begin{array}{c}\text { Epidermis } \\
\text { height }\end{array}$ & $\begin{array}{l}\text { Leaf } \\
\text { yield }\end{array}$ & $\begin{array}{c}\text { Rhizome } \\
\text { yield }\end{array}$ & Foliage & Menthol \\
\hline Xylem & -0.162 & - & - & - & - & - & - & - & - & - & - \\
\hline Phloem & 0.345 & 0.252 & - & - & - & - & - & - & - & - & - \\
\hline Xylem/cortex & $-0.823^{* *}$ & 0.408 & -0.243 & - & - & - & - & - & - & - & - \\
\hline Xylem/phloem & $-0.829 * *$ & 0.143 & $-0.757 * *$ & $0.741 * *$ & - & - & - & - & - & - & - \\
\hline Metaxylem vessels diameter & 0.270 & 0.214 & 0.505 & -0.556 & -0.464 & - & - & - & - & - & - \\
\hline Epidermis height & $0.955^{* * *}$ & -0.179 & 0.523 & $-0.778 * *$ & $-0.893 * *$ & 0.250 & - & - & - & - & - \\
\hline Leaf yield & 0.541 & 0.464 & 0.360 & -0.111 & -0.500 & 0.000 & 0.464 & - & - & - & - \\
\hline Rhizome yield & 0.342 & $0.643^{*}$ & 0.018 & 0.037 & -0.036 & -0.143 & 0.321 & 0.536 & - & - & - \\
\hline Foliage & 0.018 & $0.929 * * *$ & 0.270 & 0.371 & 0.000 & 0.000 & 0.000 & $0.714^{* *}$ & $0.750 * *$ & - & - \\
\hline Menthol & 0.396 & 0.571 & 0.072 & -0.074 & -0.143 & -0.107 & 0.393 & 0.571 & $0.964 * * *$ & $0.714^{* *}$ & - \\
\hline Menthone & -0.378 & -0.107 & 0.378 & 0.259 & 0.000 & 0.250 & -0.286 & -0.357 & $-0.679 *$ & -0.286 & $-0.786^{* *}$ \\
\hline
\end{tabular}

Notes: see Table 3.

\section{Discussion}

Phloem to xylem ratio was $1: 3$ in peppermint plants breeds before and after in vitro improvement, and in two cultivars Mama and Lubenchanka it was $1: 4$. This data differs from the Likars'ka-4 breed study data, in which the ratio 1:6 is characteristic (Rusetskaya \& Antsyishkina, 2016). It should be noted that cortex thickness decreased against xylem thickness, which has significantly increased in four breeds. It is important to emphasize that among the trees tested by us only Lebedyna Pisnia and Mama breeds are high in menthol, which facilitates activation of terpene synthesis and their accumulation in leaves, and significant yield increase in raw materials of peppermint plants breeds was observed in consequence of improvement. It is not unlikely that high content of menthol and other terpenoid structure compounds is related to the cells' differentiation in sprouts, which does not contradict studies (Klee, 1991) in which xylogenesis intensification under control of auxin type enzymes was found.

The greatest essential oil quantity was observed in the peppermint breeds Lebedyna Pisnia, Lubenchanka and Mama and was 3.84\%, 4.02\% and $3.98 \%$ respectively, as was stated in our previous research (Talankova-Sereda et al., 2018). This has great value for these breeds which are cultivated in Ukraine for derivation of essential oil as the basic product.
Whereas content of menthol and other terpenoids influences differentiation processes of cells in sprouts, it is necessary to compare data about menthol content and metaxylem vessels diameter. In previous research, Ukrainian selection peppermint breeds differed by menthol content in essential oil (Talankova-Sereda et al., 2018). In three high menthol peppermint breeds the metaxylem vessel's diameter decreased after cloning in comparison with vegetatively propagated plants: in the Lebedyna Pisnia breed mentol content ranged from $70.1 \%$ in vegetatively propagated plants to $74.1 \%$ in improved $(70.1 \% / 74.1 \%)$, in the Mama breed ( $72.0 \% / 72.6 \%)$, in the Lidiia breed $(60.5 \% / 61.4 \%)$; the high menthol Lubenchanka breed is an exception, its metaxylem vessels' diameter increased and mentol content was $68.0 \% / 68.8 \%$; in two low menthol breeds, Ukrains'ka Pertseva (38.4\% /44.2\%) and Chornolysta $(30.7 \%$ $133.3 \%$ ) metaxylem vessels' diameter increased (Talankova-Sereda et al., 2018)

The Lebedyna Pisnia and Mama peppermint breeds were produced by selection in Zhovtneva hybrid seed generation, but cortex thickness significantly increased in cloned plants of the Mama breed $(\mathrm{P}<0.01)$.

The Chornolysta breed was produced by unitary selection from genesic generation of English mint more than thirty years ago, therefore it was rather stable by cortex and phloem thickness, but xylem thickness after application of the in vitro method increased $(\mathrm{P}<0.05)$. 
Xylem to cortex ratio and phloem to xylem ratio indices fluctuated in different breeds from 2.3 to 4.7. Phloem to xylem ratio index increase testifies to the adaptive strategy of the plants to their immediate environment. All sections of histochemical preparations of improved in vitro culture plants had less intensive staining by peroxidase and M-lignin in comparison with vegetatively propagated plants. Therefore one can assume that improved plants contain fewer infectious agents as they have undergone chemotherapy and have been propagated in sterile conditions, they are more resistant to biotic and abiotic factors, thereby they have decreased intensive synthesis of peroxidase, as antioxidant, which activates in consequence of stresses (Andreeva, 1988; Lagrimini et al., 1997; Kazan et al., 1998; Sasaki et al., 2002). It is considered that peroxidase and lignin quantity increases at viral infection penetration, and this promotes protection against pathogens (Burhanova, 2006). Peroxidase activity is also closely associated with cell walls' lignification (Rogozhin, 2004), which was less pronounced in peppermint plants after in vitro culture, unlike yearling Iris sibirica plant-regenerants, which by contrast differ by high M-lignin content (Tikhomirova et al., 2018).

In all Ukrainian selection peppermint plants breeds after improvement and micropropagation in in vitro culture, a clear trend to leaf cover and yield increase was observed. In our research, the greatest air-dry leafage has been observed in the Chornolysta breed after improvement in in vitro culture, which increased yield by $720 \mathrm{~kg} / \mathrm{ha}, 51.4 \%$ greater than in vegetatively propagated plants.

Positive correlation between epidermis height and cortex thickness indices and negative correlation between epidermis height and xylem/ cortex and xylem/phloem ratios was revealed in plants, insofar as caulis secondary thickening occurs as a result of depositing by cambium of elements of the conductive system, primarily xylem, whereas epidermis cells and cortex parenchyma thickness almost do not change. Such correlation indices specify more intensive secondary growth in improved plants. Positive correlation between morphometrical indices of epidermis cells height and cortex thickness in plants after improvement in in vitro culture also characterises coordination or orderly growth and stretching of cells (Kuriyama \& Fukuda, 2001; Fukuda \& Ohashi-Ito, 2018).

Positive correlation between xylem thickness and leaf cover is revealed in improved plants, whilst this index in vegetatively propagated plants significantly less, which in addition indicates more intensive development and growth of in vitro propagated plants.

The general feature of the Lidiia and Ukrains'ka Pertseva peppermint plant breeds is reduction in xylem thickness after in vitro culture. By this fearture they differed from the other tested breeds. Lidiia breed yield increased by $200 \mathrm{~kg} / \mathrm{ha}$ (7.6\%), Ukrains'ka Pertseva breed by $530 \mathrm{~kg} / \mathrm{ha}$, which is $34.9 \%$. Correlation coefficients, which defined close interrelations between xylem thickness and leaf cover $(\mathrm{r}=0.90)$ and leaf yield and leaf cover $(r=0.88$ against $r=0.76)$, considerably increased when excluding them from the general correlation analysis (when correlation analysis was conducted between indices of all tested samples).

A close interrelation between general rhizomes' weight and menthol content in leaves deserves special attention. After in vitro culture this index appeared to be at the level $r=0.96$, and in vegetatively propagated plants it was high enough $(r=0.94)$. Inverse interrelation between rhizome yield and menthone content $(\mathrm{r}=-0.81)$ was observed in vegetatively propagated plants, which was caused by the fact that this product is a menthol precursor. Negative correlation $(\mathrm{r}=-0.68)$ between rhizome yield and menthone content in improved plants appeared due to the greater quantity of the end product of synthesis (menthol).

Xylem thickness increase is usually associated with the high auxin content in tissues, which differentiate, and formation of vessels with smaller diameter (Evert, 2016; Fukuda \& Ohashi-Ito, 2018).

In general, the correlation coefficient between menthone and menthol in in vitro culture improved plants is -0.89 , while in vegetatively propagated plants it is -0.64 , which confirms the advantages of clonal micropropagation over traditional propagation.

In vitro culture promoted weight increase of rhizomes by $27.0 \%$ on average in all tested breeds within one vegetation year. Rhizome weight increase testifies to high assimilation and assimilants outflow of the above-ground part with formation of reserve substances. Simultaneously, general mass increase of leaves is directly associated with the plants' total assimilation surface area and, accordingly, leads to increase in the amount of products available for terpenoid synthesis in phloem tissues with their subsequent transport to glandular structures - trichomes (Tissier, 2012), which positively influences derivation of target products from vegetative raw materials. This is confirmed by data about increase in quantity major of components in improved plants (Talankova-Sereda et al., 2018).

Consequently, anatomical and histochemical studies of sprouts of Ukrainian selection peppermint plants breeds reveal certain principles associated with passage of plants through in vitro culture. First of all, they are associated with increased intensity in xylogenesis (except for the Lidiia and Ukrains'ka Pertseva breeds). The most expressed process of xylogenesis increase was observed in the Mama and Chornolysta breeds, and the latter had maximally increased raw materials yield by $51.4 \%$ after improvement.

The Lebedyna Pisnia and Mama breeds, which are characterised by the most intensive development on almost all tested anatomical and morphological indices after in vitro culture, showed rhizomes yield increase by $40.4-40.1 \%$, leaf cover by $21.0 \%$ and $13.0 \%$, leaves yield by $37.1 \%$ and $26.6 \%$ accordingly.

It should be noted that essential oil quantity also increased in all plant breeds after in vitro cultivation (Talankova-Sereda et al., 2018), while there was also increase in sprouts' branching and leaf cover increase, and accordingly, greater quantity of inflorescences, which is obviously associated with improvement.

\section{Conclusions}

The Lebedyna Pisnia and Mama breeds are recognised as the most effective breeds, and this makes it possible to recommend them for industrial cultivation. Improvement considerably improved the productivity of best state breed Chornolysta, which increased its air-dry raw materials yield by $51.4 \%$ and essential oil quantity per hectare by $54.4 \%$. Anatomical and histochemical features changes in in vitro cultivation conditions are cultivar-specific and appear within the genotype. We confirmed the advantages of improvement in in vitro conditions and clonal micropropagation over peppermint traditional vegetative propagation by significant increase in the following indices: essential oil quantity, air-dry raw materials and rhizome yield, leaf cover, xylogenesis intensity. Correlation indices indicate more intensive secondary growth in improved plants. Positive correlation between xylem thickness and leaf cover in improved plants was revealed. This additionally indicates more intensive development and growth of plants propagated in vitro.

I express gratitude to candidate of agricultural sciences A. A. Kljuvadenko and candidate of biological sciences A. F. Lihanov for making it possible to conduct research in "Problem research laboratory of phytovirology and biotechnology of the National University of Life and Environmental Sciences of Ukraine", for the experience they passed on, their important advice and valuable comments, and for the equipment and materials supplied.

\section{References}

Aleksandrova, L. P. (1994). Biosintez fenolnyih soedineniy v protsesse formirovaniya pobega sosnyi obyiknovennoy [The biosynthesis of phenolic compounds during the formation of the shoot of Scots pine]. Krasnoyarsk State University, Krasnoyarsk (in Russian).

Andreeva, V. A. (1988). Ferment peroksidaza: Uchastie v zaschitnom mehanizme rasteniy [Peroxidase enzyme: Participation in the plant defense mechanism]. Nauka, Moscow (in Russian).

Burhanova, G. F. (2006). Anionnyie peroksidazyi kak komponent ustoychivosti rasteniy pshenitsyi $\mathrm{k}$ fitopatogennyim gribam [Anionic peroxidases as a component of the resistance of wheat plants to phytopathogenic fungi]. Bashkir State Agrarian University, Ufa (in Russian).

Burlat, V., Oudin, A., Courtois, M., Rideau, M., \& St-Pierre, B. (2004). Co-expression of three MEP pathway genes and geraniol 10-hydroxylase in internal phloem parenchyma of Catharanthus roseus implicates multicellular translocation of intermediates during the biosynthesis of monoterpene indole alkaloids and isoprenoid-derived primary metabolites. The Plant Journal, 38, 131-141. 
Derzhavna farmakopeya Ukrayiny [The State Pharmacopoeia of Ukraine] (2014). Ukrayinskiy naukoviy farmakopeyniy tsentr yakosti Likarskih zasobiv, Kharkiv.

Endo, A., Sawada, Y., Takahashi, H., Okamoto, M., Ikegami, K., Koiwai, H., Seo, M., Toyomasu, T., Mitsuhashi, W., Shinozaki, K., Nakazono, M., Kamiya, Y., Koshiba, T., \& Nambara, E. (2008). Drought induction of Arabidopsis 9-cisepoxycarotenoid dioxygenase occurs in vascular parenchyma cells. Plant Physiology, 147(4), 1984-1993.

Eshhenko, V. O., Kopitko, P. G., Kostogriz, P. V., \& Oprishko, V. P. (2014) Osnovy naukovyh doslidzhen' $\mathrm{v}$ agronomiji [Fundamentals of research in agronomy]. Edelvejs \& K, Vinnitsa (in Ukrainian).

Fukuda, H., \& Ohashi-Ito, K. (2019). Vascular tissue development in plants. Plant Development and Evolution. Current Topics in Developmental Biology, 131, 141-160.

Furst, G. G. (1979). Metody anatomo-gistohimicheskogo issledovanija rastitelnyh tkaney [Methods of anatomic-histochemical studies of plant tissues]. Nauka, Moscow (in Russian)

Grodzins'kij, A. M. (1992). Likars'ki roslyny: Enciklopedychnyj dovidnyk [Medicinal plants: An encyclopedic guide]. Ukrajins'ka enciklopedija imeni M. P. Bazhana, Ukrajins'kyj Vyrobnycho-Komercijnyj Centr Olimp, Kyiv (in Ukrainian).

Hawkins, S., \& Boudet, A. (2003). Defence lignin' and hydroxycinnamyl alcohol dehydrogenase activities in wounded Eucalyptus gunnii. Forest Pathology, 33(2), 91-104.

Kawano, K. (2003). Thirty years of cassava breeding for productivity: Biological and social factors for success. Crop Science, 43(4), 1325-1335.

Kazan, K., Murray, F. R., Goulter, K. C., Llewellyn, D. J., \& Manners, J. M. (1998). Induction of cell death in transgenic plants expressing a fungal glucose oxidase. Molecular Plant-Microbe Interaction, 11, 555-562.

Kirichenko, E. B. (2008). Ekofiziologija miaty: Produkcionnyj process i adaptacionnyj potencial [Ecophysiology of mint: Production process and adaptive potential]. Main Botanical Gardens named after N. V. Tsitsin, Nauka, Moscow (in Russian).

Klee, H., \& Estelle, M.(1991). Molecular genetic approachesto plant hormone biology. Annual Review of Plant Physiology and Plant Molecular Biology, 42, 529-551.

Kleyn, R. M., \& Kleyn, T. D. (1974). Metody issledovaniya rasteniy [Research methods in plant science]. Kolos, Moscow (in Russian).

Knyazyuk, O. V., \& Kozak, V. V. (2017). Vplyv strokiv visadzhuvannya rozsady ta shyryni mizhryad' na formuvannya produktyvnosti m'yaty pertsevoyi [Sowing time and row-spacing width influence on peppermint plants productivity formation]. Journal Agrobiology, 1, 156-160 (in Ukrainian).

Kuin', N. T. N., Gravel', I. V., \& Filippova, A. V. (2011). Sravnitel'nyj morfologo-anatomicheskij analiz syr'ja mjaty perechnoj i mjaty polevoji [Comparative morphological and anatomical analysis of Mentha piperita L. and Mentha arvensis L.]. Izvestiya of Altai State University, Biological Sciences, 71, 30-33 (in Russian).

Kuriyama, H., \& Fukuda, H. (2001). Regulation of tracheary element differentiation. Journal of Plant Growth Regulation, 20(1), 35-51.

Lagrimini, L. M., Joly, R. J., Dunlap, J. R., \& Liu, T. T. Y. (1997). The consequence of peroxidase overexpression in transgenic plants on root growth and development. Molecular Biology of Woody Plants, 33, 887-895.

Lange, D. M., Wildung, M. R., Stauber, E. J., Sanchez, C., Pouchnik, D., \& Croteau, R. (2000). Probing essential oil biosynthesis and secretion by functional evaluation of expressed sequence tags from mint glandular trichomes. Proceedings of the National Academy of Sciences, 97(6), 2934-2939.

Little, C. H. A., \& Pharis, R. P. (1995). Hormonal control of radial and longitudinal growth in the tree stem. In: Gartner, B. L. (ed.). Plant Stems: Physiology and Functional Morphology. Academic Press, San Diego. Pp. 281-319.

Mehdi Talebi, S., Ghorbani Nohooji, M., Yarmohammadi, M., Azizi, N., \& Matsyura, A. (2018). Trichomes morphology and density analysis in some "Nepeta" species of Iran. Mediterranean Botany, 39(1), 51-62.
Mishchenko, L. T., Dunich, A. A., Dashchenko, A. V., \& Molchanets, O. V. (2014). Vidovoe raznoobrazie virusov, porazhayuschih rasteniya roda Mentha [Species diversity of viruses infecting plants of Mentha genus]. University Proceedings, Volga Region, Natural Sciences, Biology, 2(6), $29-45$ (in Russian).

Mishhenko, L. T., Kucenko, N. I., \& Talankova-Sereda, T. E. (2016). Osobennosti diagnostiki virusnyh boleznej (Mentha piperita L.) i optimizacija mikroklonal'nogo razmnozhenija dlja ozdorovlenija [Features diagnosis of viral diseases of Mentha piperita L. and optimization of microclonal breeding for improvement of plants]. Sbornik nauchnyh trudov Mezhdunarodnoj nauchno-prakticheskoj konferencii "Biologicheskie osobennosti lekarstvennyh i aromaticheskih rastenij i ih rol' v medicine". Shherbinskaja Tipografija, Moscow. Pp. 282-287 (in Russian).

Moloc'kij, M. J., Vasil'kivs'kij, S. P., Knjazjuk, V. I., \& Vlasenko, V. A. (2006) Selekcija i nasinnyctvo sil's'kogospodars'kyh roslyn [Selection and seed production of agricultural plants]. Vishha Osvita, Kyiv (in Ukrainian).

Murashige, T., \& Skoog, F. A. (1962). Revised medium for rapid growth and bio assay with tobacco tissue culture. Plant Physiology, 15(3), 473-497.

Narváez-Vásquez, J., \& Ryan, C. A. (2004). The cellular localization of prosystemin: A functional role for phloem parenchyma in systemic wound signaling. Journal of Plant Biology, 218(3), 360-369.

Rogozhin, V. V. (2004). Peroksidaza kak component antioksidantnoi sistemy zhivykh organizmov [Peroxidase as a component of the antioxidant system of living organisms]. Giord, Saint Petersburg (in Russian).

Sasaki, Y., Ishikawa, J., Yamashita, A., Oshima, K., Kenri, T., Furuya, K., Yoshino, C., Horino, A., Shiba, T., Sasaki, T., \& Hattori, M. (2002). The complete genomic sequence of Mycoplasma penetrans, an intracellular bacterial pathogen in humans. Nucleic Acids Research, 30, 5293-5300.

Shelud'ko, L. P. (2004). M'jata perceva (selekcija i nasinnyctvo) [Mint pepper (breeding and seedling)]. Vydavnyctvo Poltava, Poltava (in Ukrainian).

Talankova-Sereda, T. E., Kolomiets, J. V., Likhanov, A. F., Sereda, A. V., Kucenko, N. I., \& Shkopinskiy, E. O. (2018). Effect of clonal reproduction on quantitative indices and component composition of essential oil of peppermint varieties. Regulatory Mechanisms in Biosystems, 9(3), 340-346 (in Ukrainian).

Talankova-Sereda, T. E., Kolomiec, J. V., \& Grigorjuk, I. P. (2016). Klonal'ne mikrorozmnozhennja sortiv m'jaty percevoji (Mentha piperita L.) Ukrajins'koji selekciji [Clonal micropropagation of peppermint (Mentha piperita L.) varieties of Ukrainian breeding]. Plant Varieties Studying and Protection, 31, 50-56 (in Ukrainian).

Tanasienko, F. S. (1985). Efirnye masla. Soderzhanie i sostav v rastenijah [Essentia oils. Content and composition of plants]. Naukova Dumka, Kyiv (in Ukrainian).

Tikhomirova, L. I., Bazarnova, N. G., \& Sinitsyna, A. A. (2018). Histochemica study of xylem cells in in vitro culture of Iris sibirica L. Russian Journal of Bioorganic Chemistry, 44(7), 860-869 (in Russian).

Tissier, A. (2012). Trichome specific expression: Promoters and their applications. In: Çiftçi, Y. O. (Ed.). Transgenic plants - Advances and limitations. InTech, Weinberg, Germany. Pp. 353-378.

Tkachenko, K. G. (2011). Efiromaslichnye rastenija i efirnye masla: Issledovanija i perspektivy, sovremennye tendencii izuchenija i primenenija [Essential oil plants and essential oils: Research and perspectives, modern trends in studying and application]. Bulletin of Udmurt University, Series Biology, Earth Sciences, 1, 88-100 (in Russian).

Uggla, C., Magel, E., Moritz, T., \& Sundberg, B. (2001). Function and dynamics of auxin and carbohydrates during earlywood/latewood transition in Scots pine. Plant Physiology, 125, 2029-2039.

Veljovic-Jovanovic, S., Kukavica, B., Stevanovic, B., \& Navari-Izzo, F. (2006) Senescence and drought-related changes in peroxidase and superoxide dismutase isoforms in leaves of Ramonda serbica. Journal of Experimental Botany, 57(8), 1759-1768.

Yusupova, Z. R., Khairullin, R. M., \& Maksimov, I. V. (2006). The activity of peroxidase in various cell fractions of wheat plants infected with Septoria nodorum Berk. Russian Journal of Plant Physiology, 53(6), 807-813 (in Russian). 